\title{
IMPACT OF MORTALITY AND LIVE BODY WEIGHT PERFORMANCE IN BROILER CHICKEN ON THE INCOME GENERATION BY SMALL FARMERS IN RURAL ASSAM (INDIA)
}

\author{
Borah M K ${ }^{1}$, Kalita A ${ }^{1}$, Sarmah B ${ }^{2}$, Saikia K ${ }^{3}$, Pathak $S^{3}$, Sarmah P C ${ }^{3 *}$ \\ ${ }^{1}$ College of Veterinary Science, Khanapara, Guwahati-781022 \\ ${ }^{2}$ Deptt. of Commerce, Gauhati University, Guwahati-781014 \\ ${ }^{3}$ Lakhimpur College of Veterinary Science, Joyhing, North Lakhimpur-787051 \\ Received - September 11, 2019; Revision - October 28, 2019; Accepted - November 06, 2019 \\ Available Online-December 25, 2019
}

DOI: http://dx.doi.org/10.18006/2019.7(6).613.618

\author{
KEYWORDS \\ Mortality \\ Live weight \\ Broiler Chicken \\ Assam
}

\footnotetext{
* Corresponding author

E-mail: pcsarmah@gmail.com (Dr. Prabhat Chandra Sarmah)
}

Peer review under responsibility of Journal of Experimental Biology and Agricultural Sciences.

Production and Hosting by Horizon Publisher India [HPI] (http://www.horizonpublisherindia.in/).

All rights reserved.

\begin{abstract}
The aim of this study was to investigate the disease problem, mortality pattern and live weight performance of broiler chicken flocks raised in the rural farms of Assam and compare the results of current study with the corresponding data obtained from an instructional farm. On the basis of obtained results level of income generation by farmers from the sale proceeds was also determined in this study. The rural farms witnessed higher (17.21\%) mortality than that of instructional farm $(2.16 \%)$. Average live weight performance of birds at a market age of 49 days was $2.34 \mathrm{~kg} / \mathrm{bird}$ in the rural farms against an average record of $2.79 \mathrm{~kg} / \mathrm{bird}$ in the instructional farm. Post-mortem examination of dead birds showed that the farms were affected with coccidiosis $(44.44 \%)$, colibacillosis $(22.22 \%)$ hydropericardium syndrome $(15.55 \%)$, gout $(13.33 \%)$, brooder pneumonia $(8.88 \%)$ and enteritis $(6.67 \%)$ of which enteric infections were found to be the major cause of death. Experimental subclinical coccidiosis resulted an average $451.67 \mathrm{~g}$ less weight gain compared to healthy controls and this also paralleled to the lower performance observed in the rural farms. The farmers were found to incur $15.38 \%$ and $13.65 \%$ losses of sale proceeds obtained in instructional farm due to higher mortality and lesser weight gain respectively with a total $29.03 \%$ income loss. The findings of the study warrant technical support to untrained farmers in the neglected areas of litter management, health care and disease prevention for a better prospect towards improving the farmers' income.
\end{abstract}

All the articles published by Journal of Experimental Biology and Agricultural Sciences are licensed under a Creative Commons Attribution-NonCommercial 4.0 International License Based on a work at www.jebas.org.

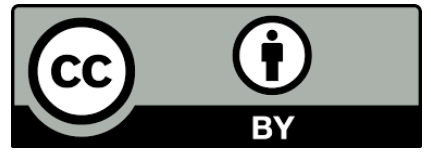




\section{Introduction}

Broiler chicken farming is a popular commercial enterprise among small and marginal farmers of developing countries including India (Shreya \& Murthy, 2017). It is a short-term business, which can be done in several batches within a year with less capital investment and high economic return in a span of 6-7 weeks per batch. Farmers with awareness on the benefit of this venture towards employment generation for both male and females and regular flow of income are easily attracted to adopt broiler farming on a commercial basis (Adetola \& Simeon, 2013). Technical efficiency and adoption of newer strategies are recognized to be important components for obtaining best possible weight in broilers at market age and maximize the profit margin (Samarakoon \& Samarsinghe, 2012).

Although nutrition plays an important role in attainment of $2.5 \mathrm{~kg}$ standard live weight per broiler at 42 days of age (Cresswell, 2005), one may fail to achieve the target due to diseases which affect the birds' performance. Diseases are frequently observed in birds raised on deep litter (Riddel \& Kong, 1992). Faecal contamination of litter is a key factor for occurrence of several infectious and non-infectious diseases capable of causing ill health of birds in clinical and subclinical forms (Adamu, 2015). Apart from viral diseases, coccidiosis, necrotic enteritis, colibacillosis and salmonellosis are considered to be the common infectious enteric diseases of birds responsible for decreased feed intake, nutrient absorption, increased feed conversion ratio, reduced body weight gain, high morbidity and mortality thus leading to a huge economic loss (Dahiya et al,. 2006; Shirzad et al., 2011; Abera et al., 2017). Higher medication cost to fight diseases, development of drug resistance, drug residue and public health risk of consumption of contaminated broiler meat are some other aspects which adversely impact upon improperly managed farms (Muhammad et al., 2010; Timbermont et al., 2011).

Broiler farming in Assam and other North-East Indian states has gained momentum in the past decade due to its high potentialilty on income generation. As a result, the unemployed youths have been taking up broiler farming on commercial basis. Unlike other parts of India, this region however experiences heavy rainfall, recurrent waves of flood during monsoon, moderate temperature and a very high humidity throughout the year. All these climatic factors are conducive for proliferation and longevity of disease agents in endemic areas. Prevalence of various infectious disease agents in broiler chicken has been worked out in this region (Buragohain \& Kalita, 2010; Borah et al., 2017; Kalita et al., 2018). However there is paucity of information on the growth performance, mortality pattern and income generation by rural farmers adopting broiler farming as a commercial enterprise for livelihood. The present study was undertaken to evaluate the performance of the broiler farms adopted by small and marginal farmers in Assam on the basis of bird mortality and income generation.

\section{Materials \& Methods}

The field investigation was conducted during June'2015-May'2016 at 74 broiler chicken farms in undivided Kamrup, Morigaon, Darrang and Jorhat districts of Assam which is situated in northeast region of India. Single visit was made to the farms for collection of data through discussion with farmers, access to farm records wherever available, personal observation on farm management, necropsy of dead birds and laboratory investigation. The farm data included the broiler breeds, flock, size, vaccination, medication, nutrition, litter management, bird mortality and live body weight performance at 7 weeks market age. General information on farmers' personal data such as educational status, training and experience of broiler framing were also obtained during discussion. Deep litter quality and hygiene status in the farms were noted through personal observation. A total of 190 birds found dead in the farms on different visiting days were necropsied in the farm premises and causes of death were ascertained on the basis of gross pathological findings observed at necropsy. Data on bird mortality, live body weight (bwt) attainment at 7 weeks market age and sale proceeds at a farm gate price of Rs. $75.00 / \mathrm{kg}$ live bwt of broilers maintained with all technical efficiency in the Instructional Poultry Farm of the Lakhimpur College of Veterinary Science, North Lakhimpur (Assam) were obtained to compare with the respective field data analyzed in the form of average and percentage calculation. A preliminary experiment was conducted with Institutional Animal Ethics Committee approval to assess the influence of an enteric disease due to coccidia on the bwt performance of broilers. For this, 6 broiler chicks at 2 weeks of age were infected each by oral inoculation of $5 \times 10^{4}$ laboratory sporulated oocyst of coccidia belonging to Eimeria acervulina, E. tenella and E. maxima species. Equal number of birds was kept as uninfected control. All birds of both the groups were maintained in separate wire netted cages with non-medicated feed and water supplied ad libitum. Birds were observed for faecal positivity to oocysts of coccidia, clinical signs and mortality during the experiment. Birds were weighted individually before initiation of the experiment and at weekly interval for 5 weeks thereafter. Body weight performance in the experimental group was compared with that of healthy control. Financial gain/loss in rural farms on the basis of sale proceeds and mortality loss was calculated in comparison with respective data generated from the instructional farm.

\section{Results \& Discussion}

Most of the farmers involved in broiler chicken farming in the present survey areas were non-matriculate $(83.33 \%)$ while only $16.66 \%$ were having educational qualifications as matriculate and 
above. None of the farmers had acquired any training on poultry farming but the day-to-day problems were solved through consultancy services. The present findings are in agreement with Satapathy et al. (2017) who reported lot of farmers in India were small scale uneducated and untrained. Similar data were also projected from a neighboring country, Bangladesh where more than $70 \%$ farmers had secondary level of education and majority had no training on broiler farming (Islam et al., 2014). Training, education, farming experience and extension contact were recognized to be the significant factors affecting the profitability of small scale broiler farmers (Kawsar et al., 2013; Satapathy et al., 2017).

Broilers were raised on deep litter placed mostly over Kutcha floor (97.91\%) while only $2.08 \%$ farmers used pucca floor. In current study, deep litter used by $6.25 \%$ farmers were fresh for each broiler batch while $93.75 \%$ farms used the same litter for raising multiple (2-4) broiler batches. Deep litter is recognized to be the important source of infection to the broilers which are easily infected with pathogens from poorly managed litters (Yegani \& Korver, 2008; Abera et al., 2017) through faecal-oral route.

Farm history on disease occurrence in order of farmers' perception level included chronic respiratory disease (CRD-97.92\%), infectious bursal disease (IBD-79.17\%), hydro-pericardium syndrome $(72.92 \%)$, colibacillosis $(58.33 \%)$, gout $(31.25 \%)$ and coccidiosis $(27.08 \%)$ as the diseases affecting their farms (Table-1). Post-mortem examination of 190 dead birds however revealed coccidiosis to be the commonest disease diagnosed in $44.44 \%$ of the farms followed by collibacilosis $(22.22 \%)$, hydro-pericardium syndrome $(15.55 \%)$ and gout $(13.33 \%)$. According to the body system involved, gastro-intestinal system was found mostly affected with infectious organisms. Similar examination of dead birds at the instructional farm recorded occurrence of only colibacillosis and respiratory tract infection. Earlier, Borah et al. (2017) also recorded certain microbial diseases in broiler chickens of Assam. Kalita et al. (2018) reported coccidiosis in clinical and subclinical forms to be the most common and this was found to be in conformity with the present finding. Occurrence of coccidiosis at a rate much higher than the farmers' perception level indicated lack of awareness and poor management procedures practised by untrained farmers in this region where environmental conditions of high rainfall, high humidity and moderate temperature are influencing propagation of coccidia and other pathogenic microbes in the deep litter. This agreed to the disease induced high mortality in birds observed as observed by Buragohain \& Kalita (2010) and Yegani \& Korver (2008).

Looking into the data on bird mortality and live bwt attained in birds at 7 weeks rearing period, the rural farmers witnessed $1.5 \%$ $41.6 \%$ (Average $17.21 \%$ ) mortality and $1.90-2.87 \mathrm{~kg}$ (Av. $2.34 \mathrm{~kg}$ ) live bwt attained in surviving birds in the rural farms (Table 2). In contrast, there was only $2.03-2.30 \%$ (Av. $2.16 \%$ ) bird mortality and 2.62-2.97 kg (Av. $2.79 \mathrm{~kg}$ ) live bwt recorded in birds at the instructional farm. Higher mortality and lesser bwt attainment in birds also reflected poor management problems in the rural farms (Zahir-ud-Din et al., 2005; Bera et al., 2010). Profit and loss accounts prepared on the basis of average loss due to mortality and

Table 1 Disease problems in broiler chicken farms of rural Assam

\begin{tabular}{|c|c|c|}
\hline \multirow{2}{*}{ Disease } & \multicolumn{2}{|c|}{ No. of farm positivity (\%) as per } \\
\hline & $\begin{array}{c}\text { Farm History } \\
(\mathbf{N}=\mathbf{4 8})\end{array}$ & Post mortem examination $(\mathrm{N}=45)$ \\
\hline Coccidiosis & $13(27.08 \%)$ & $20(44.44 \%)$ \\
\hline Infectious bursal disease (IBD) & $38(79.17 \%)$ & - \\
\hline Chronic Respiratory Disease (CRD) & $47(97.92 \%)$ & - \\
\hline Hydropericardium Syndrome & $35(72.92 \%)$ & $7(15.55 \%)$ \\
\hline Heat Stress & $5(10.42 \%)$ & - \\
\hline Gangrenous dermatitis & $3(6.25 \%)$ & - \\
\hline Gout & $15(31.25 \%)$ & $6(13.33 \%)$ \\
\hline Colibacillosis & $28(58.33 \%)$ & $10(22.22 \%)$ \\
\hline Enteritis & $3(6.25 \%)$ & $3(6.67 \%)$ \\
\hline Magotted wound & $1(2.08 \%)$ & - \\
\hline Brooder Pneumonia & $3(6.25 \%)$ & $4(8.88 \%)$ \\
\hline
\end{tabular}

Journal of Experimental Biology and Agricultural Sciences http://www.jebas.org 
Table 2 Comparison of averages in mortality rate, live weight attainment at 7 weeks \& income level per flock of 100 birds in rural farms \& instructional farms

\begin{tabular}{|lcc|}
\hline Parameters & Rural farms & Instructional farm \\
\hline Average mortality $(\%)$ & $17.21(1.50-41.60)$ & $2.16(2.03-2.30)$ \\
\hline Average live weight $(\mathrm{kg})$ & $2.34(1.90-2.87)$ & $2.79(2.62-2.97)$ \\
\hline Sales Proceeds (INR)* & $14,529.64$ & $20,473.02$ \\
\hline Total loss in INR (\%) & $-5943.38(29.03)$ & - \\
\hline Loss in INR due to mortality $(\%)$ & $-3149.22(15.38)$ & - \\
\hline Loss in INR due to live weight performance $(\%)$ & $-2794.16(13.65)$ & - \\
\hline
\end{tabular}

*Calculated on the basis of Rs.75/kg live body weight of birds as Farm Gate price.

Table 3 Statement of average financial loss due to bird mortality and reduced live body weight in rural broiler chicken farms $(\mathrm{N}=26)$ compared to instructional farm

\begin{tabular}{|cccc|}
\hline \multirow{2}{*}{$\begin{array}{c}\text { Proportion of loss incurred } \\
\text { Nortality }\end{array}$} & $1(3.85)$ & Reduced live weight & Total number of farms (\%) \\
\hline No loss & $25(96.15)$ & $1(3.85)$ & Nil \\
\hline Loss & $10(40.00)$ & $25(96.15)$ & $26(100.00)$ \\
\hline$-<10 \%$ & $6(24.00)$ & $9(36.00)$ & $1(3.85)$ \\
\hline$-10-20 \%$ & $8(32.00)$ & $10(40.00)$ & $5(30.77)$ \\
\hline$-20-30 \%$ & $0(0.00)$ & $6(24.00)$ & $6(23.07)$ \\
\hline$-30-40 \%$ & $1(4.00)$ & $0(0.00)$ & $3(11.53)$ \\
\hline$-40-50 \%$ & $0(0.00)$ & $0(0.00)$ & $3(11.53)$ \\
\hline$-50-60 \%$ & & $0(0.00)$ & \\
\hline
\end{tabular}

live bird sale proceeds it was found that the rural farms incurred loss on an average $29.03 \%$ of the sale proceeds obtained in the instructional farm. The loss incurred by the rural farms included $15.38 \%$ due to mortality and $13.65 \%$ due to reduction in live bwt of birds sold. The farms had to lose on average Rs. 209.25/bird due to mortality and Rs. 33.75/bird for reduction of $450 \mathrm{~g}$ live bwt/bird. Performance of only one rural farm $(3.85 \%)$ was almost identical to the instructional farm while the remaining $96.85 \%$ farms were found to have incurred $10-60 \%$ of total $(29.03 \%)$ losses when compared with the sale proceeds of the instructional farm (Table 3). Highest loss due to mortality and reduced live weight reached upto $50 \%$ and $30 \%$ of the respective losses incurred by the farms. Profit and loss in the rural farms of the present study was calculated on the basis of bwt performance and mortality witnessed by comparing with those of the instructional farm since, these two are considered to be the important economic traits that determine the net profit or loss in broiler industry (Zahir-ud-Din et al., 2005; Bera et al., 2010). The farmers expect to earn good revenue fetched from bird sale on live bwt basis when mortality rates are negligible (Afzal \& Khan, 2017).
Birds experimentally infected with coccidia parasites attained $1170.0 \mathrm{~g}( \pm 58.31)$ mean bwt compared to $1621.67 \mathrm{~g}( \pm 26.54)$ bwt observed in the healthy group (Table 4). Thus coccidia infection caused an average $451.67 \mathrm{~g}$ less bwt production per bird and it amounted to $27.83 \%$ sale proceeds loss when compared with the performance of healthy control birds of the experiment. Experimental finding might be parallel to the field situation where the birds also weighed $450 \mathrm{~g} / \mathrm{bird}$ on average less than that of instructional farm. This confirms that the economic losses caused by coccidia affecting the gastro-intestinal tract of the birds are enormous (Kumar et al., 2015). Coccidiosis not only affects the birds but also predisposes them to suffer from bacterial infections of the gut to produce a total loss in the broiler industry (Dahiya et al., 2006). Any abnormality in the gastro-intestinal tract can disturb the digestion of food nutrients with resultant increase in the feed conversion ratio, which is another determinant factor of profitability (Bandara \& Dassanayake, 2006; Kawsar et al., 2013) in farms. Moreover high cost of feeds and chicks also affect the cost of production especially in the small scale farming as compared to medium and large scale farming (Mohsin et al., 
Table 4 Average body weight performance in birds with experimental coccidiosis

\begin{tabular}{|ccc|}
\hline Week of Infection & Average weight $(\mathrm{g})$ in healthy birds $(\mathrm{N}=6)$ & Average weight $(\mathrm{g})$ in infected birds $(\mathrm{N}=6)$ \\
\hline Initial (Pre-infection) & $146.67 \pm 2.47$ & $148.0 \pm 1.22$ \\
\hline $1^{\text {st }}$ week (Post infection) & $343.33 \pm 4.77$ & $232.0 \pm 8.46$ \\
\hline $2^{\text {nd }}$ week & $615.0 \pm 9.92$ & $390.80 \pm 14.22$ \\
\hline $3^{\text {rd }}$ week & $964.17 \pm 21.92$ & $717.0 \pm 49.03$ \\
\hline $4^{\text {th }}$ week & $1203.33 \pm 36.09$ & $895.0 \pm 39.94$ \\
\hline $5^{\text {th }}$ week & $1621.67 \pm 26.54$ & $1170.0 \pm 58.31$ \\
\hline
\end{tabular}

N.B.- Average $451.67 \mathrm{~g}$ less body weight gain in birds experimentally infected with coccidia and incurring $27.83 \%$ INR loss compared to healthy birds; Average $450 \mathrm{~g}$ less body weight gain in birds of rural farms as compared to the instructional farm.

2008). The present finding on reduced live bwt performance in birds with coccidiosis agreed to Bera et al. (2010) claiming a minimum of $0.1 \mathrm{~kg}$ weight loss due to subclinical forms of coccidiosis. Since profit making is the ultimate goal of any commercial activity, the rural farmers are seemed to have enough scope to increase the profitability by availing effective training on broiler farming through regular flock health monitoring (Keirs et al., 1991) and adoption of better management procedures for mortality reduction as envisaged by previous workers (Singh et al., 2010; Samarakoon \& Samarsinghe, 2012).

\section{Conclusion}

Data generated through the present field investigation provided a useful insight into economic performance of rural small-scale farmers engaged in commercial broiler farming in Assam. Higher mortality and lesser body weight at market age recorded in broiler chickens reflected lack of training and practical experience of farmers on proper management procedures. Enteric infections remained as the major challenge to the broiler farming with deep litter system where farmers need to take effective steps to maintain the intestinal health of birds through litter management and adoption of better hygiene and sanitation procedures.

\section{Acknowledgement}

The authors are thankful to the Dean, College of Veterinary Science, Guwahati and the Associate Dean, Lakhimpur College of Veterinary Science, North Lakhimpur for the facilities provided to conduct this field investigation.

\section{Conflict of Interest}

The authors declare that they have no conflict of interest.

\section{References}

Abera D, Abebe A, Begna F, Tarekegn A, Alewi M (2017) Growth performance, feasibility and carcass characteristic of Cobb-500 commercial broiler under small scale production in Western Ethiopia. Asian Journal of Poultry Science 11: 49-56.

Adamu M (2015) Evaluation of risk factors associated with coccidiosis in broiler of selected farms of Ethiopia. African Journal of Basic and Applied Sciences 7: 36-40.

Adetola A, Simeon O (2013) Economic assessment of raising different broiler strains. Asian Journal of Poultry Science 7: 75-82.

Afzal M, Khan M (2017) Economic analysis of broiler farms: A case study of district lower Dir. Sharhad Journal of Agriculture 33: 183-188.

Bandara RMAS, Dassanayake DMWK (2006) A quantitative analysis of factors affecting profitability of small scale broiler production. The Journal of Agricultural Science 2: 45-50.

Bera AK, Bhattacharya D, Pan D, Dhara A, Kumar S, Das SK (2010) Evaluation of economic losses due to coccidiosis in poultry industry in India. Agricultural Economics Research Review 23: 91-96.

Borah MK, Islam R, Sarma M, Mahanta JD, Kalita N (2017) Prevalence and seasonal variation of certain microbial diseases in Kamrup and Kamrup (Metro) districts of Assam. International Journal of Chemical Studies 5: 724-726.

Buragohain R, Kalita G (2010) Assessment of mortality pattern of broiler under intensive system of management in Mizoram. Tamil Nadu Journal of Veterinary and Animal Sciences 6: 239-241.

Cresswell D (2005) The nutritional requirements of today's broiler. Asian Poultry Magazine May, 18-21.

Dahiya JP, Wilkee DC, Vankessel AG, Drew MD (2006) Potential Strategies for controlling necrotic enteritis in broiler chickens in post-antibiotic era. Animal Feed Science Technology 129: 68-88.

Islam F, Hossain MH, Akhtar A, Hossain MS (2014) Prospects and challenges in broiler farming of Barguna district in Bangladesh. Journal of Bioscience \& Agriculture Research 2: 44-51. 
Kalita A, Sarmah PC, Borah MK, Hussain L, Bhattacharjee K (2018) Magnitude of Coccidia infection in small scale broiler chicken farms of rural Assam (India). International Journal of Current Microbiology \& Applied Science 7: 3399-3403.

Kawsar MH, Choudhury SD, Raha SK, Hossain MM (2013) An analysis of factors affecting profitability of small scale broiler farming in Bangladesh. World's Poultry Science Journal 69: 676-686.

Keirs RW, Magee DL, Purchase HG, Ciderwood R, Boyle CR, Freund J (1991) A new system for broiler flock health monitoring. Preventive Veterinary Medicine 11: 95-103.

Kumar S, Garg R, Ram H, Maurya PS, Banerjee PS (2015) Gastrointestinal Parasitic infections in chickens of upper Gangetic plains of India with special reference to poultry coccidiosis. Journal of Parasitic Diseases 39: 22-26.

Mohsin AQ, Riaz R, Asad S, Mustaq A (2008) Profitability analysis of broiler production in Rawalpindi district. Pakistan Journal of Agricultural Sciences 45: 514-519.

Muhammad M, Muhammad LU, Ambali AG, Mani AU (2010) A survey of early chick mortality on small scale poultry farms in Jos, Central Nigeria. International Journal of Poultry Science 9: 446-449.

Riddell C, Kong XM (1992) The influence of diet on necrotic enteritis in broiler chickens. Avian Diseases 36: 499-503.

Samarakoon SMR, Samarsinghe K (2012) Strategies to improve the cost effectiveness of broiler production. Tropical Agricultural Research 23: 338-346.

Satapathy D, Sharma A, Paswan JK, Sarkar S, Varun TK (2017) Economic broiler farming: Scope and limitations. Indian farmers 4: 393-405.

Shirzad MR, Seifi S, Gheisari HR, Hachesoo BA, Habibi H, Bujmehrani H (2011) Prevalence and risk factors for subclinical cocciosis in broiler chicken farms in Mazardaram Province, Iran. Tropical Animal Health \& Production 43: 1601-1604.

Shreya A, Murthy C (2017) Marketing channels and problems of commercial broiler rearing in Dharwad district. International Journal of Commerce and Business Management 10: 25-28.

Singh VP, Sharma VK, Sidhu MS, Kingra HS (2010) Broiler production in Punjab - An economic analysis. Agricultural Economics Research Review 23: 315-324

Timbermont L, Haesebrouch F, Ducatella R, Van-Immerseel F (2011) Necrotic enteritis in broiler: An update review on pathogenesis. Avian Pathology 40: 341-347.

Yegani M, Korver DR (2008) Factors affecting intestinal health of poultry. Poultry Science 87. 2052-2063.

Zahir-ud-Din, Farooq M, Durani FR, Chand N, Ahmad J (2005) Status of broilers produced in Swat, Pakistan. Journal of Agriculture and Social Sciences 1: 327-331. 